\title{
TARI JINGKRAK SUNDANG SEBAGAI BENTUK KRITIK SOSIAL DALAM MASYARAKAT DI KABUPATEN MAGELANG
}

\author{
Puput Putriaji \\ Bintang Hanggoro Putra \\ Universitas Negeri Semarang \\ Email : pputriaji@gmail.com \\ Bintanghanggoro@yahoo.co.id
}

\begin{abstract}
Abstrak
Banyaknya permasalahan sosial menuai berbagai kritik dari masyarakat, kritik tersebut disampaikan dengan berbagai cara seperti pepe,demo, berkesenian, dan sebagainya. Sebuah karya tari berjudul tari Jingkrak Sundang yang digarap oleh Sujono merupakan salah satu bentuk kritik dari permasalahan sosial berupa eksploitasi alam di kaki gunung merapi oleh penambangan pasir sehingga merusak keseimbangan alam. Tari Jingkrak Sundang adalah tari kreasi baru bertema hewan dengan gerak pengembangan dari gerak tari kerakyatan Magelang dengan iringan perkusi dan tata rias dan busana menyerupai hewan. Kritik sosial dalam tari Jingkrak Sundang terdapat dalam gerak dan pola lantai, tata rias dan tata busana. Aspek yang dikritik oleh tari Jingkrak Sundang adalah birokrasi atau pemerintah yang tidak tegas dalam mengambil tindakan terhadap penambangan pasir di kaki gunung Merapi yang menggunakan alat konstruksi berat dan kesadaran masyarakat dalam menjaga kelestarian alam. Efek yang dihasilkan dari kritik sosial dalam tari Jingkrak Sundang adalah berlakunya peraturan larangan menggunakan alat berat seperti Bego masuk ke kawasan kaki gunung di daerah Magelang. Penelitian ini diharapkan dapat menjadi acuan koreografer tari Jingkrak Sundang untuk terus mengembangkan tari Jingkrak Sundang agar lebih baik dan terus berkarya di bidang kesenian dengan mengambil tema alam sekitar.
\end{abstract}

Kata kunci : Bentuk Pertunjukan, Kritik Sosial, Tari Jingkrak Sundang

\section{PENDAHULUAN}

Manusia dalam menjalani kehidupan selalu berhadapan dengan berbagai permasalahan. Permasalahan tersebut tidak hanya sebatas permasalahan individu saja, tetapi juga berkembang menjadi permasalahan masyarakat luas. Permasalahan muncul ketika perbedaan-perbedaan kepentingan menjadi pemicu keruhnya suatu hubungan sosial dalam suatu kelompok atau masyarakat yang akhirnya menjadi masalah-masalah sosial. Manusia memerlukan komunikasi untuk menyampaikan permasalahan tersebut dan mengembalikan manusia kembali kepada hakikatnya.

Seluruh lapisan masyarakat pasti pernah mengalami permasalahan sosial, baik yang berprofesi sebagai buruh, petani, pegawai negeri sipil, maupun seniman. Seniman sebagai bagian dari masyarakat tidak menghindari masalah-masalah sosial tersebut. Seniman yang produktif, cerdas dan peka terhadap masalah sosial tersebut akan mampu mengolahnya dalam karya seni sebagai cerminan kondisi sosial budaya masyarakat dengan tujuan tidak hanya menghibur saja, tetapi juga 
mendidik, mengkritik, dan memperbaiki keadaan melalui ajakan yang tertuang dalam karyanya, baik di bidang seni musik, seni rupa, maupun seni tari.

Tari berkaitan dengan persoalan-persoalan bahasa dalam keberadaan dan cara-cara penyajiannya, karena peristiwa tari sebenarnya adalah juga peristiwa komunikasi (Sumaryono 2011:13). Tari sebagai salah satu cabang seni tidak terlepas dari kehidupan masyarakat, untuk itu tari merupakan suatu media komunikasi yang baik. Tari sebagai media komunikasi bisa dijadikan sebagai wacana sosial, dimana tari bisa menunjukkan sebuah ekspresi, realitas kehidupan, dan kritik melalui simbol dari gerak tari. Bagi seorang koreografer, karya tari merupakan sarana untuk mengungkapkan ide-ide dan pemikiran koreografer. Hal ini dilakukan oleh koreografer sebagai ungkapan perasaan atau bahkan protesnya terhadap realita masalah sosialnya. Realitas sosial tersebut misalnya ketertindasan, kemiskinan, ketidakadilan, keserakahan, kejahatan, dan sebagainya. Bentuk protes yang diungkapkan koreografer melalui karya tari bisa disebut sebagai suatu bentuk kritik sosial.

Sebuah realitas sosial berupa kerusakan alam terjadi di daerah lereng gunung Merapi yang diakibatkan oleh aktivitas penambangan pasir yang silakukan secara semena-mena, yakni menggunakan alat konstruksi berat sehingga berdampak buruk bagi hutan dan warga sekitar. Masalah tersebut membuat seorang seniman di Dusun Keron Kabupaten Magelang bernama Sujono membuat kritik sosial melalui penciptaan sebuah tari yang berjudul tari
Jingkrak Sundang. Tari Jingkrak Sundang adalah tarian yang menggambarkan amarah hewanhewan yang habitatnya dirusak oleh tangan manusia yang tidak bertanggung jawab. Sujono menyelipkan kritik sosial pada tari Jingkrak Sundang ke dalam gerak yang tegas dan dinamis serta rias tari yang dominan menggunakan warna merah.

Istilah critic dalam bahasa Inggris sudah ada sejak tahun 1558, dan bahasa Yunani kritikos yang erat hubungannya dengan krinein yang berarti memisahkan, mengamati, menilai, dan menghakimi (Merriam Webster dalam Bahari 2008:1). Menurut Adinegoro, kritik adalah salah satu ciri dan sifat penting dari peristiwa otak manusia, sehingga kritik dapat dijadikan dasar untuk berfikir dan mengembangkan pikiran (1958:10). Kritik sosial adalah salah satu bentuk komunikasi dalam masyarakat yang bertujuan atau berfungsi sebagai kontrol terhadap jalannya sebuah sistem sosial atau proses bermasyarakat (Akhmad Zaini Akbar 1997: 8). Berdasarkan pernyataan di atas dapat disimpulkan bahwa kritik sosial adalah suatu bentuk komunikasi untuk menilai atau menghakimi suatu peristiwa sosial sebagai kontrol terhadap sebuah proses bermasyarakat. Kritik sosial dalam penelitian ini diwujudkan oleh Sujono sebagai koreografer dengan media tari Jingkrak Sundang, dimana kritik tersebut terdapat dalam bentuk pertunjukan tari.

Pengertian bentuk adalah wujud diartikan sebagai hasil dari berbagai elemen tari yaitu gerak, ruang dan waktu; dimana secara bersama-sama elemen-elemen itu mencapai vitalitas estetis (Hadi 
2007:24). Menurut Soedarsono (2001:5) sebuah pertunjukan merupakan perpaduan antara beberapa aspek penting seperti lakon, pemain, busana, iringan, tempat pentas, dan penonton. Berdasarkan pengertian di atas peneliti menyimpulkan bahwa bentuk pertunjukan adalah wujud dari kecenderungan kreatif berupa sebuah tontonan dimana terdapat unsur yang merupakan perpaduan dari beberapa aspek penting seperti lakon, pemain, busana, iringan, tempat pentas, dan penonton. Menurut M. Jazuli (2008:13) unsur utama dalam tari adalah gerak, sedangkan unsur-unsur pendukung atau pelengkap sajian tari adalah iringan (musik), tema, tata rias busana (kostum), tata rias wajah, tempat (pentas atau panggung), tata lampu atau sinar, dan tata suara.

Gerak dalam tari merupakan gerakan yang dilakukan untuk mengungkapkan pengalaman batin dan perasaan seseorang, dengan harapan untuk mendapatkan tanggapan (Sedyawati 1986:23). Gerak dalam tari Jingkrak Sundang terbagi atas gerak murni dan maknawi, pada gerak maknawi inilah yang mengadung ekspresi kritik sosial.

Musik sebagai iringan atau partner gerak adalah memberikan dasar irama pada gerak ibaratnya musik sebagai rel untuk tempat bertumpunya rangkaian gerak ( Hidajat 2005:53). Komponen musik yang dipergunakan untuk tari ialah ritme, degupan, melodi, frase, dan harmoni (La Meri 1986:121).

Penataan rias adalah salah satu unsur koreografi yang berkaitan dengan karakteristik tokoh. Tata busana untuk tari lebih menekankan orientasinya pada konsep koreografi, disamping ada pertimbangan praktis yaitu faktor peraga tarinya (Hidajat 2005:60-63).

Tema adalah pokok pikiran, gagasan utama atau ide dasar (Jazuli 2008:18). Sumber tema dapat dilihat, didengar, dipikirkan, dan dirasakan. Tema dapat digali dari fenomena sehari-hari, kondisi, situasi atau apapun yang telah dipastikan sebagai "sesuatu" yang mendorong perasaan untuk diungkap (Hidayat 2005:30).

Pelaku adalah penyaji dalam pertunjukan, baik yang terlibat langsung maupun tidak langsung untuk menyajikan bentuk pertunjukan. Beberapa pertunjukan ada yang hanya melibatkan pelaku laki-laki, pelaku perempuan, dan menampilkan pelaku laki-laki bersamaan dengan pelaku wanita. Pelaku pertunjukan dilihat dari umur dan usia dapat bervariasi, misalnya anak-anak, remaja atau orang dewasa (Kusumastuti 2012:3).

Tempat pertunjukan merupakan tempat yang digunakan untuk mempertunjukkan karya seni dan berbagai kegiatan seni pertunjukan (Kusumastuti 2012:3). Ruang pentas pada dasarnya dibedakan menjadi dua, yaitu pentas prosenium dan panggung terbuka. Pentas prosenium adalah dimana penonton hanya bisa melihat pertunjukan dari satu sisi saja, sedangkan panggung terbuka lebih banyak digunakan untuk pemanggungan tontonan tari tradisi dengan jarak penonton lebih dekat sehingga menghasilkan suasana yang lebih akrab (Widyastutieningrum dan Wahyudiarto 2014:51).

Pola lantai adalah garis-garis lantai yang dilalui atau dibuat oleh penari, bisa berupa garis lurus ataupun garis lengkung. Kedua garis tersebut dapat dibuat berbagai 
macam bentuk garis dalam area pentas, seperti garis zig-zag, diagonal, lingkaran, lengkung, dan sebagainya (Jazuli 2008:96).

\section{METODE}

Metode penelitian yang digunakan dalam penelitian ini adalah metode kualitatif. Peneliti dalam menguraikan permasalahan menggunakan data kualitatif tentang Tari Jingkrak Sundang untuk diuraikan secara deskriptif. Data diperoleh melalui observasi, wawancara, dan dokumentasi. Analisis data yang digunakan dalam penelitian ini menggunakan analisis data model interaktif yang dikemukakan oleh Milles dan Huberman (2014:19), yakni mengemukakan tiga hal utama, yaitu reduksi data, penyajian data, dan penarikan kesimpula/verifikasi sebagai sesuatu yang jalin-menjalin pada saat sebelum selama, dan sesudah pengumpulan data dalam bentuk yang sejajar untuk membangun wawasan umum. Teknik uji keabsahan data dalam penelitian ini menggunakan triangulasi teknik. Sugiyono (2013:373) menyatakan bahwa triangulasi teknik untuk menguji kredibilitas data dengan cara mengecek data kepada sumber yang sama dengan teknik yang berbeda, misalnya data diperoleh dengan wawancara, lalu dicek dengan observasi, dokumentasi, atau kuesioner.

\section{HASIL DAN PEMBAHASAN}

Tari Jingkrak Sundang merupakan suatu bentuk kritik sosial, untuk mengetahui kritik yang terkandung dalam tari Jingkrak Sundang maka perlu dibahas mengenai bentuk pertunjukan tari Jingkrak Sundang terlebih dahulu.

\section{Bentuk Pertunjukan Tari Jingkrak Sundang}

Bentuk pertunjukan tari Jingkrak Sundang dapat dilihat dari unsur utama berupa gerak dan unsur pendukung berupa iringan, tata rias, tata busana, pelaku, tata pentas dan pola lantai

\section{Gerak Tari Jingkrak Sundang}

Gerak dalam sebuah pertunjukan merupakan unsur utama. Gerak-gerak yang ditarikan dalam tari Jingkrak Sundang kebanyakan gerak yang gagah. Tari Jingkrak Sundang memiliki delapan ragam gerak, yakni ragam gerak mlayu, nebah bumi, laku telu, ngicik, dadung ngawuk, pati, mendem, nawur.

\section{Iringan Tari Jingkrak Sundang \\ Iringan merupakan unsur pendukung dalam sebuah} pertunjukan tari. Iringan dalam tari Jingkrak Sundang menggunakan empat alat musik yaitu kendang, bedug, bass drum, dan bende. Iringan dalam tari Jingkrak Sundang tidak menggunakan lirik atau lagu, hanya menggunakan instrumen perkusi. Iringan tari Jingkrak Sundang memiliki dinamika tempo yang bervariasi, pada bagian awal iringan tari Jingkrak Sundang menggunakan tempo cepat, kemudian pada bagian tengah iringan tari Jingkrak Sundang menggunakan tempo yang lambat kemudian pada akhir tarian menggunakan tempo cepat. Iringan pada tari Jingkrak Sundang sewaktu-waktu bisa berubah dan berkembang, hal itu disebabkan adanya daya kreatifitas penata musik.

\section{Tata Rias Tari Jingkrak Sundang}

Tata rias merupakan unsur pendukung dalam penyajian tari. 
Penampilan sebuah tarian akan lebih menarik jika didukung oleh penataan rias pada penari. Tata rias pada penyajian tari Jingkrak Sundang lebih dominan menggunakan body painting. Perias dalam penyajian tari Jingkrak Sundang adalah para penari sendiri, karena para penari telah diberikan pengetahuan tentang tata rias dengan menggunakan body painting.

Alat yang digunakan dalam tata rias tari Jingkrak Sundang adalah kuas cat, sedangkan bahannya menggunakan cat tembok warna putih, merah dan hitam. Penggunaan cat tembok pada tata rias tari Jingkrak Sundang karena lebih fleksibel dan mudah untuk dibersihkan. Jenis body painting yang digunakan dalam tata rias tari Jingkrak Sundang adalah rias karakter hewan, yaitu rias menyerupai hewan yang dikreasikan agar lebih menarik. Rias karakter hewan bervariasi, bergantuk jenis karakter hewan yang diperankan oleh penari.

\section{Tata Busana Tari Jingkrak Sundang}

Busana adalah salah satu unsur pendukung dalam sebuah tarian. Selain berfungsi sebagai penutup badan, busana dalam tari juga memiliki tujuan untuk mempertegas karakter, selain itu juga ada busana yang memiliki makna tertentu, baik dari segi warna maupun bentuk. Kostum yang dipakai penari Jingkrak Sundang adalah sebagai berikut:

\section{Kuluk}

Kuluk adalah aksesoris menyerupai topi atau irahirahan. Kuluk dilengkapi dengan dua tanduk berwarna putih gading atau emas yang terbuat dari busa dan busa panjang yang dibungkus dengan kain hitam dan diikat setiap $2 \mathrm{~cm}$ menyerupai rambut gimbal. Kuluk dihiasi dengan jamang kreasi berwarna emas dan dilengkapi dengan manik-manik yang berwarnawarni.

2. Uwok

Uwok adalah tiruan moncong hewan yang terbuat dari kayu dengan tambahan rambut palsu di kedua sisinya dan karet atau ban dalam sebagai tali pengikat saat dipakai. Bentuk uwok bermacam-macam sesuai dengan karakter hewan yang diperankan oleh para penari. Uwok memiliki 11 jenis, yaitu uwok gajah, badak, celeng atau babi, kijang, harimau, landak, sapi, singa, buaya, anjing, tapir, dan trenggiling.

3. Klat bahu

Klat Bahu adalah aksesoris yang dipakai di kedua lengan tangan penari. Klat bahu pada tari Jingkrak Sundang terbuat dari busa ati yang dibentuk motif ukiran dan dilapisi dengan kain batik.

4. Gelang

Gelang adalah aksesoris yang dipakai di kedua pergelangan tangan. Gelang bisa terbuat dari bahan logam ataupun bahan sintetis seperti busa atau plastik. Gelang pada tari Jingkrak Sundang terbuat dari busa ati yang dibentuk seperti segitiga dan ditumpuk dengan busa ati berbentuk belah ketupat, dilapisi dengan bahan plastik bermotif berwana emas dan manik-manik berwarna pink dan hijau.

5. Rapek

Rapek adalah hiasan pinggang 
yang terbuat dari kain
menyerupai rumbai-rumbai.

6. Celana

Celana yang digunakan pada kostum tari Jingkrak Sundang adalah celana berukuran tiga per empat berwarna hitam polos dengan tambahan rumbai-rumbai dari benang wol berwarna merah dan kuning di samping dan pada ujung celana. Penggunaan warna hitam pada busana tari Jingkrak Sundang bermaksud agar suasana rimba dalam tarian ini lebih terasa oleh penonton yang melihatnya.

7. Krincing

Krincing adalah gelang kaki yang besar, terbuat dari ban dalam yang dilapisi dengan busa dan dilengkapi dengan gongseng (lonceng).

\section{Pelaku Tari Jingkrak Sundang}

Pelaku dalam sebuah pertunjukan tari adalah orang yang berperan dalam sebuah pertunjukan tari tersebut. Pelaku tari Jingkrak Sundang adalah anggota Sanggar Saujana. Pelaku tari Jingkrak Sundang terdiri dari penari dan pemusik. Seluruh anggota Sanggar Saujana dibekali ilmu body painting, menari, dan menjadi pemusik iringan tari yang diciptakan oleh Sujono, dan sebagai perupa. Jadi, jika ada salah satu personil dari penari berhalangan tampil pada acara tertentu, maka anggota Sanggar Saujana yag lain bisa menggantikan. Tari Jingkrak Sundang ditarikan oleh penari pria, karena karakter dari tari Jingkrak Sundang tegas dan brangasan.

\section{Tata Pentas Tari Jingkrak Sundang}

Penataan pentas dalam suatu penyajian tari perlu diperhatikan karena berhubungan dengan dari sisi mana penonton melihat pertunjukan tersebut. Tari Jingkrak Sundang bisa tampil di lapangan maupun di dalam ruangan, yang beda hanya tempat penontonnya saja, untuk arah hadap penari tetap pada satu arah.

\section{Pola Lantai Tari Jingkrak Sundang}

Pola lantai adalah garis-garis imajiner yang dibuat oleh penari untuk membuat suatu lintasan atau formasi dalam suatu pertunjukan agar terkesan lebih menarik dan tidak monoton. Tari Jingkrak Sundang merupakan tari massal, sehingga untuk membuat penampilan tari Jingkrak Sundang lebih menarik ditambahkan pola lantai. Pola lantai dalam tari Jingkrak Sundang tidak semata-mata hanya untuk membuat pertunjukan lebih menarik, tetapi juga memiliki makna tersendiri. Pasangan pola lantai dengan ragam gerak dalam tari Jingkrak Sundang tidak bisa diubah karena jika diubah pemaknaannya juga bisa berubah. Pola lantai yang digunakan dalam tari Jingkrak Sundang adalah pola lantai horizontal yang digunakan pada saat gerak nebah bumi, pola lantai lingkaranyang digunakan pada saat gerak pati, pola lantai diagonal yang digunakan pada saat gerak mendem, dan pola lantai kombinasi berupa gabungan antara pola lantai diagonal dengan lingkaran yang digunakan pada saat gerak dadung awuk.

\section{Masalah Sosial yang Dikritik dalam Tari Jingkrak Sundang}

Masalah sosial adalah gejala atau fenomena yang timbul dalam kehidupan masyarakat. Permasalahan sosial yang dikritik dalam tari Jingkrak Sundang terdiri dari dua unsur masalah sosial. Kedua unsur masalah tersebut adalah masalah 
birokrasi dan masalah kesadaran masyarakat.

\section{Birokrasi}

Birokrasi yang dimaksud dalam hal ini adalah pemerintah. Kritik dalam Tari Jingkrak Sundang mengangkat permasalahan khusus mengenai penambangan pasir di Kabupaten Magelang. Mudahnya perijinan mendirikan penambangan pasir di hutan di kaki gunung membuat para pengusaha baik lokal maupun dari luar negeri tergiur untuk membangun penambangan pasir tanpa memikirkan dampak yang ditimbulkan dari penambangan pasir tersebut.

\section{Kesadaran Masyarakat}

Masalah sosial yang dikritik dalam tari Jingkrak Sundang tidak hanya secara khusus ditujukan kepada fenomena eksploitasi alam oleh penambangan pasir di Kabupaten Magelang saja, melainkan secara umum untuk kelestarian alam semesta. Masyarakat di era sekarang jarang sekali yang memperhatikan kelestarian alam. Masyarakat hanya memikirkan kehidupan saat ini tanpa memikirkan apa yang akan didapatkan anak cucunya nanti. Pemanasan global, peningkatan polusi dan membludaknya sampah memicu kerusakan alam. Melihat keadaan alam yang semakin memburuk membuat Sujono selaku koreografer tari Jingkrak Sundang tergugah untuk membuat sebuah karya tari yang bisa dijadikan sebagai kritik dan ajakan untuk menjaga alam.

\section{Bentuk Penyampaian Kritik dalam Tari Jingkrak Sundang}

Tari Jingkrak Sundang memiliki fungsi sebagai kritik sosial yang disimbolkan melalui gerak, tata rias, tata busana dan pola lantai, sehingga tari Jingkrak Sundang termasuk pada kategori kritik tidak langsung. Kritik sosial dalam tari Jingkrak Sundang disampaikan melalui interaksi simbolik dengan penonton, selain pembacaan sinopsis sebelum pertunjukan tari Jingkrak Sundang. Tidak semua bagian dari bentuk pertunjukan tari Jingkrak Sundang mengandung unsur kritik sosial, tetapi aspek tersebut tetap berfungsi untuk mendukung hal-hal dalam tari Jingkrak Sundang yang mengandung unsur kritik. Berikut adalah penjelasan makna dari simbol kritik sosial pada gerak, tata rias, tata busana dan pola lantai tari Jingkrak Sundang.

\section{Makna dan Kritik dalam Gerak Tari Jingkrak Sundang}

Gerak dalam tari terbagi menjadi dua, yaitu gerak murni yang tidak memiliki makna dan gerak maknawi. Sujono menyusun gerakan murni dan maknawi dalam tari Jingkrak Sundang guna mewujudkan tari yang berfungsi sebagai kritik sosial. Berikut adalah makna gerak maknawi dalam tari Jingkrak Sundang serta kritik yang terkandung didalamnya:

1. Makna dan Kritik dalam gerak Mlayu

Mlayu adalah gerakan berlari memasuki area panggung. Mlayu menggambarkan hewan yang berlari kebingungan karena habitat hewan yang hancur akibat dari ulah manusia. Koreografer menempatkan gerak Mlayu pada awal tarian dengan maksud mengajak penonton untuk sadar akan keadaan hutan di masa sekarang dari sudut pandang hewan.

2. Makna dan Kritik dalam gerak Nebah Bumi 
Nebah bumi merupakan simbol ketahanan, gerakan ini merupakan kode untuk berkumpul. Koreografer membuat gerak nebah bumi dengan maksud mengajak penonton untuk bersatu menjaga kelestarian alam serta melakukan perlawanan terhadap oknum yang merusak alam.

3. Makna dan Kritik dalam gerak Laku Telu

Laku telu dilakukan dengan tempo cepat. Gerakan laku telu merupakan gerakan melangkah dengan pola maju mundur, sedangkan tempo yang cepat menandakan ketegasan. Gerak langkah laku telu merupakan kritik kepada pemerintah yang kurang tegas dalam mengambil tindakan pemberhentian kepada penambangan pasir yang menggunakan alat konstruksi berat, sedangkan tempo yang cepat menandakan ketegasan, hal ini merupakan kritik kepada pemerintah pemerintah yang seharusnya tegas dalam mengambil tindakan terhadap fenomena kerusakan alam yang diakibatkan oleh penambangan pasir dengan semena-mena. Kritik tersebut lebih mengerucut pada permasalahan eksploitasi hutan di kaki gunung, dalam arti pemerintah jangan terlalu mudah mengijinkan alat-alat konstruksi berat masuk lokasi penambangan pasir di kaki-kaki gunung.

4. Makna dan Kritik dalam gerak Dadung ngawuk

Dadung ngawuk adalah gerakan mengelompok sesuai dengan jenis hewan seperti kelompok hewan pemakan rumput dan kelompok hewan pemakan daging. Kritik yang terdapat dalam ragam gerak dadung ngawuk yaitu beberapa oknum baik pengusaha maupun birokrasi yang hanya memikirkan keuntungan masing-masing kelompok saja, tanpa memikirkan kerugian yang akan diperoleh kelompok lainnya. Pengelompokkan hewan berdasarkan jenisnya juga merupakan simbol bahwa hidup antara hewan dengan manusia mungkin tidak bisa bersatu, tetapi seharusnya manusia dan hewan harus hidup saling berdampingan.

5. Makna dan Kritik dalam gerak Pati

Gerak Pati adalah ragam gerak tari Jingkrak Sundang dimana posisi penari berbaring terlentang. Pati menggambarkan hewan yang mati akibat ulah manusia. Penggambaran kematian hewan pada tari Jingkrak Sundang bermaksud untuk memberikan gambaran secara simbolis agar penonton sadar bahwa perbuatan manusia yang merusak habitat hewan akan mengakibatkan kematian pada hewan tersebut dan keseimbangan alam tidak bisa terjaga lagi.

6. Makna dan Kritik dalam gerak Mendem

Mendem tidak berarti saat dimana para penari mengalami masa intrance atau kesurupan melainkan gerakan bertempo pelan yang menyerupai orang mendem. Mendem merupakan sebuah kritik kepada birokrasi yang lamban dalam menangani kasus eksploitasi alam oleh penambangan pasir di kaki gunung.

Motif gerak mendem bertempo pelan, hal ini memiliki arti bahwa untuk mengembalikan kondisi alam seperti sebelumnya tidak bisa langsung dilakukan secara cepat, tetapi harus pelan-pelan.

7. Makna dan Kritik dalam gerak Nawur

Nawur adalah gerakan tangan seperti menebar dan mengambil. 
Motif gerak nawur merupakan simbol ajakan kepada seluruh masyarakat untuk mengembalikan alam seperti semula. Hidup pada hakikatnya tidak hanya mengambil apa yang telah disediakan oleh alam, tetapi juga harus memberi dengan cara merawat alam sekitar dan mengambil sumber daya alam secukupnya saja.

\section{Makna dan Kritik dalam Pola Lantai Tari Jingkrak Sundang}

1. Makna dan Kritik dalam Pola lantai Horizontal

Pola lantai pada saat gerakan Nebah bumi adalah pola lantai horizontal, hal ini berarti kita harus saling memperhatikan hubungan antara seluruh makhluk di bumi, baik manusia, tumbuhan maupun hewan karena semua makhluk di bumi pada hakikatnya saling membutuhkan.

2. Makna dan Kritik dalam Pola lantai Lingkaran

Pola lantai pada gerak pati membentuk pola lingkaran. Pola lantai lingkaran merupakan sebuah simbol bahwa semua yang ada di dunia saling terkait, pola lantai lingkaran juga merupakan simbol permohonan atau doa kepada Tuhan yang Maha Esa. Koreografer menggunakan pola lingkaran bermaksud agar penonton sadar bahwa semua makhluk di dunia saling membutuhkan, dan mengajak penonton untuk lebih mendekatkan diri kepada Tuhan Yang Maha Esa.

3. Makna dan Kritik dalam Pola Lantai Diagonal

Pola lantai yang digunakan pada gerak mendem adalah pola lantai diagonal. Penari membentuk satu garis diagonal merupakan simbol sebagai benang merah untuk meluruskan bahwa tindakan eksploitasi alam itu tidak benar.
Koreografer menggunakan pola lantai diagonal bermaksud untuk mengajak para penonton untuk meluruskan perbuatan eksploitasi alam oleh pihak manapun.

\section{Makna dan Kritik dalam Warna Rias Tari Jingkrak Sundang}

Tata rias dalam suatu pertunjukan tari terkadang tidak hanya berfungsi sebagai pelengkap tari saja, tetapi juga memiliki arti baik dari segi warna maupun bentuk. Tata rias wajah dan tubuh pada Tari Jingkrak Sundang menyerupai wajah hewan dengan menggunakan cat warna putih, merah dan hitam. Bentuk garis dan pola pada rias tari Jingkrak Sundang tidak memiliki makna atau kritik tersendiri, hanya untuk mempertegas karakter hewan yang diperankan oleh setiap penari tari Jingkrak Sundang. Pemilihan warna pada tata rias wajah dan tubuh tari Jingkrak Sundang memiliki makna yang sesuai dengan tema tari Jingkrak Sundang. Berikut adalah kritik yang terkandung dalam warna pada tata rias tari Jingkrak Sundang:

1. Warna merah merupakan bentuk kegeraman koreografer terhadap keadaan alam yang dirusak oleh pihak tertentu. Koreografer memilih warna merah untuk mengajak penonton memandang dari sudut pandang hewan hutan, apa yang dirasakan hewan ketika habitatnya dirusak oleh manusia.

2. Warna putih melambangkan kesucian dan ketidakberdayaan, dalam arti hewan itu pada hakikatnya suci. Ketidakberdayaan dalam hal ini berarti hewan yang tidak berdaya melawan perbuatan manusia yang telah merusak habitat mereka. Koreografer memilih warna putih dengan maksud 
mengajak penonton untuk menjernihkan pikiran dari keegoisan dalam mengambil sumber daya alam.

3. Warna hitam merupakan warna penegas pola pada riasan tari Jingkrak Sundang. Warna hitam dalam tari Jingkrak Sundang merupakan sebuah bentuk kritik kepada pemerintah bahwa seharusnya pemerintah tegas dalam melarangan membawa alat konstruksi berat beroperasi di daerah penambangan pasir dan langsung memberikan sangsi yang berat terhadap pemilik penambangan pasir tersebut.

\section{Makna dan Kritik dalam Tata busana Tari Jingkrak Sundang}

Penataan Busana pada tari

Jingkrak Sundang tidak semata-mata sebagai pelengkap tarian saja, tetapi juga memiliki makna tersendiri. Busana yang dipakai oleh penari tari Jingkrak Sundang adalah Kuluk, Uwok, Klat Bahu, Rapek, celana hitam tiga per empat, dan Krincing. Tidak semua bagian kostum memiliki arti, bagian kostum yang membuat tari Jingkrak Sundang ini unik dan memiliki arti adalah di bagian kuluk. Kuluk pada tari Jingkrak Sundang berbentuk menyerupai topi yang memiliki tanduk atau sungu. Tanduk atau sungu pada kuluk tari Jingkrak Sundang terdapat pada semua karakter hewan yang ditarikan.

Sungu atau tanduk pada kuluk berarti suatu simbol amarah atau kemurkaan hewan-hewan hutan karena habitatnya yang semakin sempit termakan oleh penambangan pasir. Sudut pandang hewan ditampilkan agar masyarakat sadar bahwa ada yang hidup dan tinggal di sekitar kita selain manusia itu sendiri, manusia hidup di dunia bersama hewan dan tumbuhan yang patut dijaga kelestariannya. Kuluk dalam tari Jingkrak Sundang juga merupakan suatu bentuk perlawanan secara simbolis terhadap birokrasi yang dengan mudah meloloskan alat bangunan berat seperti bego beroprasi di penambangan pasir di kaki gunung Merapi.

\section{Kesan dalam Iringan Tari Jingkrak Sundang \\ Iringan pada tari Jingkrak} Sundang tidak menggunakan lagu maupun syair sehingga tidak memiliki unsur kritik di dalamnya. Iringan tari Jingkrak Sundang juga sewaktu-waktu bisa berubah, dalam arti tidak ada pakem dalam komposisi iringannya. Namun iringan dalam tari Jingkrak Sundang tidak digarap hanya semata-mata sebagai pelengkap saja, tetapi juga digarap sedemikian rupa sehingga memberikan kesan tegas dan ramai, kesan tersebut yang mendukung makna yang terdapat dalam gerak, pola lantai, tata rias dan tata busana tari Jingkrak Sundang, dimana elemen-elemen tersebut mengandung unsur kritik sosial.

Suasana dalam iringan ditentukan oleh tempo iringan tari Jingkrak Sundang. Contohnya pada ragam gerak mlayu merupakan gerakan yang menggambarkan keadaan yang ramai dan rusuh, hal ini juga didukung oleh iringan tari Jingkrak Sundang yang bertempo cepat dengan memainkan seluruh alat musik yang digunakan secara serempak. Ragam gerak mendem merupakan gerakan yang menggambarkan pemerintah yang lambat dalam menangani kasus eksploitasi alam yang disebabkan oleh penambangan pasir, gerak yang 
pelan dan tidak mengeluarkan banyak tenaga didukung oleh iringan yang bertempo pelan juga.

\section{Efek yang dihasilkan dari kritik sosial dalam tari Jingkrak Sundang}

Sebuah kritik ditujukan untuk sebuah pembenahan sesuatu yang salah agar kembali kepada keadaan yang benar atau keadaan yang seharusnya. Berhasil atau tidaknya suatu kritik dapat dilihat dari ada atau tidaknya efek yang dihasilkan.

Kritik sosial dalam tari Jingkrak Sundang ditujukan khususnya kepada pengusaha penambangan pasir agar penambangan tersebut ditutup atau setidaknya alat-alat bangunan berat seperti Bego tidak masuk dengan mudahnya ke daerah hutan di kakikaki gunung. Tari Jingkrak Sundang ditampilkan di berbagai macam acara, dari acara kesenian sampai acara yang diadakan oleh pemerintah.

Selang tahun 2009 sampai sekarang, dengan adanya kritik sosial yang disampaikan melalui tari Jingkrak Sundang membuahkan hasil, yakni alat-alat bangunan berat tidak beroperasi di wilayah penambangan pasir lagi, dan beberapa perusahaan penambangan pasir besar disana telah ditutup, hanya penambang pasir lokal yang masih beroperasi menggunakan tenaga manual.

Penutupan Penambangan pasir ilegal dan penarikan alat konstruksi berat yang beroperasi di kawasan penambangan pasir di lereng gunung Merapi tentu bukan semata-mata hanya karena kritik yang disampaikan dalam bentuk tari Jingkrak Sundang saja, tetapi juga karena pengaruh kritik yang disampaikan melalui aksi yang lain. Tari Jingkrak Sundang merupakan salah satu faktor yang menyebabkan penambangan pasir tersebut ditutup. Setelah masyarakat mengungkapkan kritik dengan berbagai cara, termasuk melalui tari Jingkrak Sundang, pada tahun 2014 penambangan pasir yang menggunakan alat berat telah ditutup. Penutupan penambangan pasir tersebut dibuktikan dengan adanya Peraturan Bupati Magelang Nomor 6 Tahun 2014 tentang Usaha Pertambangan, khusus penambangan dengan menggunakan alat berat di berbagai tempat di kawasan itu tidak diperbolehkan (Atmoko. http:// antarajateng.com/ detail/ penambang-pasir-merapi-

ditertibkan.html, Selasa, 02 September 2014 18:37:38 WIB).

Masyarakat sebagai penonton khususnya warga sekitar Kecamatan Sawangan sudah mulai sadar akan efek negatif yang dihasilkan dari kurangnya memperhatikan alam. Masyarakat sekitar Kecamatan Sawangan mulai mengurangi kegiatan penambangan pasir di kaki gunung, mereka hanya mengambil pasir seperlunya, dalam arti tidak memeras atau mengeksploitasi alam.

\section{SIMPULAN DAN SARAN}

Tari Jingkrak Sundang merupakan tari kreasi baru yang disusun oleh Sujono. Tari Jingkrak Sundang merupakan bentuk tari kelompok, bisa ditampilkan di dalam ruangan maupun di lapangan. Unsur pendukung tari Jingkrak Sundang meliputi gerak, iringan, tata rias, tata busana, pelaku, dan pola lantai. Gerak tari Jingkrak Sundang sangat dipengaruhi oleh gerak-gerak tari tradisi yang berkembang di Magelang. Iringan tari Jingkrak 
Sundang menggunakan alat musik kendang, bedug, bass drum, dan bende. Riasan wajah dan tubuh yang digunakan pada tari Jingkrak Sundang menggunakan body painting menyerupai hewan dengan dominasi warna merah. Busana yang dipakai pada tari Jingkrak Sundang adalah kuluk atau irah-irahan, uwok, gelang, rapek, celana tiga per empat, dan krincing. Pola lantai yang dipakai adalah pola lantai garis lurus berupa garis vertikal, horizontal, dan diagonal, serta garis lengkung berupa lingkaran.

Tari Jingkrak Sundang disusun sebagai kritik kepada keadaan sosial khususnya di Magelang. Keadaan sosial yang dikritik terdiri dari dua unsur, yaitu birokrasi dan kesadaran masyarakat khususnya di Magelang. Birokrasi yang dimaksud adalah pemerintah yang tidak tegas dalam menerapkan peraturan ijin membawa alat berat untuk keperluan penambangan pasir di kaki-kaki gunung. Masalah yang kedua adalah kurangnya kesadaran masyarakat dalam menjaga kelestarian alam. Dampak yang ditimbulkan dari kedua masalah tersebut adalah kerusakan alam dan kurangnya jumlah populasi hewan di dalam hutan yang dieksploitasi tersebut. Kritik sosial pada tari Jingkrak Sundang terdapat dalam gerak, tata rias dan tata busananya. Efek yang dihasilkan dari kritik tersebut adalah perusahaan tambang pasir yang besar sudah ditutup.

Berdasarkan kesimpulan penelitian, maka penulis merekomendasikan berupa saransaran sebagai berikut:

1. Hasil penelitian ini hendaknya dapat menjadi acuan koreografer tari Jingkrak Sundang untuk terus mengembangkan tari Jingkrak
Sundang agar lebih baik dan tidak terkesan monoton.

2. Hasil penelitian ini hendaknya dapat menjadi acuan bagi Sanggar Saujana agar terus berkarya di bidang kesenian dengan mengambil tema alam sekitar.

\section{DAFTAR PUSTAKA}

Adinegoro, Djamaludin. 1958. Tata Kritik. Jakarta: Nusantara

Atmoko, M Hari. Selasa, 02 Sept $2014 \quad$ 18:37:38 WIB http://www.antarajateng.com/ detail/penambang-pasirmerapi-ditertibkan.html. (diunduh 9 Desember 2016 pukul 20:00 WIB)

Bahari, Noorman. 2008. Kritik Seni. Yogyakarta: Pustaka Pelajar

Hadi, Sumandiyo. Y. 2005. Sosiologi Tari (Sebuah Ppengenalan Awal).Yogyakarta: Penerbit Pustaka

Tari Teks dan Konteks. Yogyakarta: Pustaka Book Publisher 2014.

Koreografi (Bentuk-TeknikIsi). Yogyakarta: Cipta Media

Hidajat, Robby. 2005. Wawasan Seni Tari : Pengetahuan Praktis bagi Guru Seni Tari. Malang: Universitas Negeri Malang

Jazuli, M. 2008. Pendidikan Seni Budaya (Suplemen Pembelajaran Seni Tari). Semarang: UNNES PRESS

Kusumastuti, Eny dan Gupita, W. 2012. "Bentuk Pertunjukan Kesenian Jamilin di Desa Jatimulya Kecamatan 
Suradadi Kabupaten Tegal ".

Jurnal Seni Tari. Juni 2012.

Nomor 1:2252-6625. Hlm. 1-

11. Semarang: Universitas

Negeri Semarang

La Meri. 1986. Elemen-Elemen

Dasar Komposisi Tari. Terjemahan Soedarsono. Yogyakarta: Laliago

Maryono. 2012. Analisa Tari. Surakarta: ISI Press Solo

Miles, M.B dan Huberman, A.M. Analisis Data Kualitatif ( Buku Sumber Tentang Metode-Metode Baru). Terjemahan Tjejep R.R.Jakarta: UI-Press

Sedyawati, dkk. 1986. Pengetahuan Elemen Tari dan Beberapa Masalah Tari. Jakarta: Direktorat Kesenian, Proyek Pengembangan Kesenian Jakarta, Departemen Pendidikan dan Kebudayaan

Soedarsono. 2001. Metodologi penelitan Seni Pertunjukan dan Seni Rupa. Bandung: Masyarakat Seni Pertunjukan Indonesia

Sugiyono. 2013. Metode Penelitian Pendidikan ( Pendekatan Kuantitatif, Kualitatif, dan $R \& D)$. Bandung: ALFABETA
Sumaryono. 2011. Antropologi Tari. Yogyakarta: Badan Penerbit ISI Yogyakarta

Widyastutieningrum, S.R. dan Wahyudiarto, Dwi. 2014. Pengantar Koreografi. Surakarta: ISI Press Surakarta

Zaini Akbar, A.1997. Kritik Sosial, Pers dan Politik Indonesia, dalam Kritik Sosial dalam Wacana Pembangunan. Yogyakarta: UII Press

Ambarwangi, S., \& Suharto, S. (2013). PENDIDIKAN MULTIKULTURAL DI SEKOLAH MELALUI PENDIDIKAN SENI TRADISI. Harmonia: Journal Of Arts Research And Education, 13(1). doi:http://dx.doi.org/10.1529 4/harmonia.v13i1.2535

Indriyanto, I. (2012). PENGARUH TARI JAWA PADA TARI BALADEWAN BANYUMASAN. Harmonia: Journal Of Arts Research And Education, 11(1). doi:http://dx.doi.org/10.1529 4/harmonia.v11i1.2071 